\title{
The Microstructure and Toughness of High Tensile Strength Steels*
}

\author{
By Hiroo OHTANI,** Fukunaga TERASAKI, ${ }^{* *}$ and Tatsuro KUNITAKE**
}

\section{Synopsis}

The impact properties of some high tensile strength steels were investigated in relation to the cooling rate on continuous cooling (after austenitization) and the austenite grain size.

Results showed the existence of the optimum cooling rate for the impact transition temperature. The optimum cooling rate varied with the hardenability of a steel, and as the austenitizing temperature was raised, it shifted to the slower cooling rate.

The electron microscopic observation revealed that the structure with superior impact properties was the duplex martensite-bainite structure. The morphology of carbide in this bainite was similar to that in the lower bainite of a higher carbon steel, but the trace analysis indicated that it had the same lath-like morphology with a $\langle 111\rangle_{\alpha}\{110\}_{\alpha}$ as that in the upper bainite and the lath martensite. (This bainite in a low-carbon low-alloy steel was designated as Bainite III type in a previous paper.)

The orientation measurements of a facet pit and a fracture surface clarified that the cleavage plane was $\{100\}$. On the basis of the direct observation of fracture surface by the scanning electron microscope, the unit crack path was defined. There was experimentally better correlation between the unit crack path and the transition temperature, that is, the finer the unit crack path, the lower the transition temperature is.

The duplex martensite-bainite III structure had the finest crack path. These results suggest that the role of bainite III in the duplex structure was the partitioning of austenite grain prior to the martensite transformation.

\section{Introduction}

There have been numerous studies on the toughness of steels in relation to microstructures, and it has been well-known that the low-temperature toughness of a steel increases by refining the austenite grain size and transformation product. ${ }^{1-15)}$ Consequently, it is believed that the tempered martensite which was produced from the fine grained austenite has the most superior mechanical properties (the combination of strength and toughness). Although the quenched and tempered high tensile strength steels have been widely used, ${ }^{16)}$ the factors controlling the toughness of quenched and tempered steel have not been clarified. Recently it was reported that the dependencies of toughness on the austenite grain size were different with the steels. ${ }^{5)}$ Also, it might be noted that the fully hardened structure $(100 \%$ martensite) could be scarcely obtained in a low-carbon low-alloy steel, ${ }^{17}$ ) and the microstructure has an important role in the toughness.
In the present experiments, the impact properties of various kinds of microstructures obtained during continuous cooling for some low-carbon low-alloy high tensile strength steels were determined in detail. As the result, a characteristic phenomenon was obtained; the duplex martensite-bainite (Bainite $I I I$ type) structure formed with a little slower cooling rates than the upper critical cooling rate had the most superior impact properties.

The aims of the present study are to investigate the morphology of bainite in the duplex structure and to reveal the structural factors contributing to the toughness by the observation of the impact fracture surface in relation to microstructure with the scanning electron microscope.

\section{Experimental Procedure}

\section{Materials}

The chemical compositions of the steels used are shown in Table 1. The steel $\mathcal{N}$ is a $60 \mathrm{~kg} / \mathrm{mm}^{2}$ grade quenched and tempered high strength steel containing small amount of nickel, molybdenum, and vanadium. The steels 7 and 8 are typical of $80 \mathrm{~kg} / \mathrm{mm}^{2}$ grade quenched and tempered high strength steels containing copper, nickel, chromium, molybdedum, and vanadium, the small amount of boron being added to the steel 8 . They were hot rolled to the plate $7 \mathrm{~mm}$ in thickness with a constant rolling condition.

\section{Heat-treatments}

The heating temperatures from $900^{\circ}$ to $1200^{\circ} \mathrm{C}$ were chosen to vary the austenite grain size. Martensite, bainite, and ferrite-pearlite structures were obtained with various cooling rates on continuous cooling (mean cooling rates between $800^{\circ}$ and $500^{\circ} \mathrm{C}$ were from $200^{\circ} \mathrm{C} / \mathrm{sec}$ to $0.0075^{\circ} \mathrm{C} / \mathrm{sec}$ ). The mechanical properties were determined on these microstructures, both as continuously cooled and as tempered. The tensile properties were tested using $4 \times 6 \times 30 \mathrm{~mm}$ gauge length specimen. The impact test was made using $5 \times 10 \times 55 \mathrm{~mm}$ subsize Charpy specimen with

Table 1. Chemical compositions of steels used

\begin{tabular}{|c|c|c|c|c|c|c|c|c|c|c|c|c|c|}
\hline Steel & C & $\mathrm{Si}$ & $\mathrm{Mn}$ & $\mathrm{P}$ & $\mathrm{S}$ & $\mathrm{Cu}$ & $\mathrm{Ni}$ & $\mathrm{Cr}$ & Mo & V & B & $\mathrm{Ti}$ & sol $\mathrm{Al}$ \\
\hline $\mathcal{N}$ & 0.15 & 0.34 & 1.25 & 0.027 & 0.017 & 0.07 & 0.19 & 0.02 & 0.13 & 0.03 & - & - & 0.032 \\
\hline 7 & 0.12 & 0.30 & 0.83 & 0.004 & 0.005 & 0.30 & 1.11 & 0.53 & 0.49 & 0.03 & - & & 0.038 \\
\hline 8 & 0.14 & 0.26 & 0.89 & 0.004 & 0.005 & 0.27 & 1.04 & 0.54 & 0.50 & 0.03 & 0.004 & 0.03 & 0.044 \\
\hline
\end{tabular}

* Originally published in Tetsu-to-Hagané, 58 (1972), 434, in Japanese. English version received June $25,1971$.

* Central Research Laboratories, Sumitomo Metal Industries, Ltd., Amagasaki 660. 
$2 \mathrm{~mm} \mathrm{~V}$-notch.

\section{Microstructural Observations}

The optical microscopic observation for these specimens was carried out after etching with $2 \%$ nital.

The thin foils were used for electron microscopy. For the thin foil preparation, the bulk specimens of $1 \mathrm{~mm}$ in thickness was polished down to $0.1 \mathrm{~mm}$ chemically. The final electro-polishing was carried out in the chromic acid/phosphoric acid electrolyte. The foils were examined in the $\mathrm{HU}-200$ operated at $200 \mathrm{kV}$. The habit plane and growth direction of martensite and bainite were determined by the trace analysis.

\section{C.C.T. Diagrams}

The decomposition of austenite on continuous cooling was examined by means of dilatometry measurements using a Formaster (the specimen was $3 \mathrm{~mm}$ in diameter and $10 \mathrm{~mm}$ in length) and Leitz dilatometer (the specimen was $3.8 \mathrm{~mm}$ in diameter and $50 \mathrm{~mm}$ in length). They were continuously cooled after austenitized at $900^{\circ}$ to $1200^{\circ} \mathrm{C}$. The cooling and temperature/dilatation curves were recorded simultaneously. The C.C.T. curves were determined from the dilatation curves, microscopic observations and hardness measurements.

\section{Observations of Fracture Surface}

As for the impact fracture surface, the aspect of fracture surface was examined with a scanning electron microscope, and the relation between the surface aspect and the microstructure was shown simultaneously. The nickel coating on the fracture surface was made, then the section which was parallel to the direction of the crack propagation and orthogonal to the fracture surface was polished. It was etched with $2 \%$ nital and facet pits on the section were presented using the following reagents; ${ }^{18)}$ (A) $\mathrm{HCl} 2 \mathrm{cc}+\mathrm{H}_{2} \mathrm{O}_{2} 10 \mathrm{cc}+$ $\mathrm{H}_{2} \mathrm{O} 200 \mathrm{cc}$ (B) $\mathrm{HCl} 2 \mathrm{cc}+$ Sat. $\mathrm{FeCl}_{3} 6 \mathrm{H}_{2} \mathrm{O} 10 \mathrm{cc}+$ $\mathrm{H}_{2} \mathrm{O} 200 \mathrm{cc}(\mathrm{C}) \mathrm{CH}_{3} \mathrm{COOH} 100 \mathrm{cc}+\mathrm{H}_{2} \mathrm{O} 100 \mathrm{cc}$.

After removing the nickel coating, the fracture surface and the corresponding section were examined with the JSM-2 type scanning electron microscope. The orientation of the cleavage plane of the brittle fracture surface was determined by the orientation measurements of the facet pit and the fracture surface using a gonio-microscope.

\section{Experimental Results}

\section{Effect of Cooling Rate on Mechanical Properties}

Figures 1, 2, and 3 show the relations of the cooling rate, which is expressed in cooling time from $800^{\circ}$ to $500^{\circ} \mathrm{C}$, to the fracture transition temperature in the impact test ( $v T s)$ and tensile strength for steels $\mathcal{N}, 7$, and 8 , respectively.

In steel $\mathcal{N}$, austenitizing at $950^{\circ}$ and $1000^{\circ} \mathrm{C}$, the faster the cooling rate, the lower the vTs is. The $v$ Ts did not vary monotonously with cooling rate after austenitizing at $1200^{\circ} \mathrm{C}$, and there was the optimum cooling rate for $v T s$. As the austenitizing temperature was raised, the hardenability increased. It suggested that even though the cooling rates were same, the microstructures were different in the different austenitizing temperatures.

On the other hand, in steel 7 , the optimum point for $v$ Ts was observed even at the low austenitizing temperature and it shifted to the lower cooling rate as the austenitizing temperature was raised.

In steel 8, containing boron, the optimum point for vTs was observed clearly.

These results that the optimum point varied with the chemical composition and austenitizing temperature suggested strongly that the optimum point depended on the hardenability of a steel.

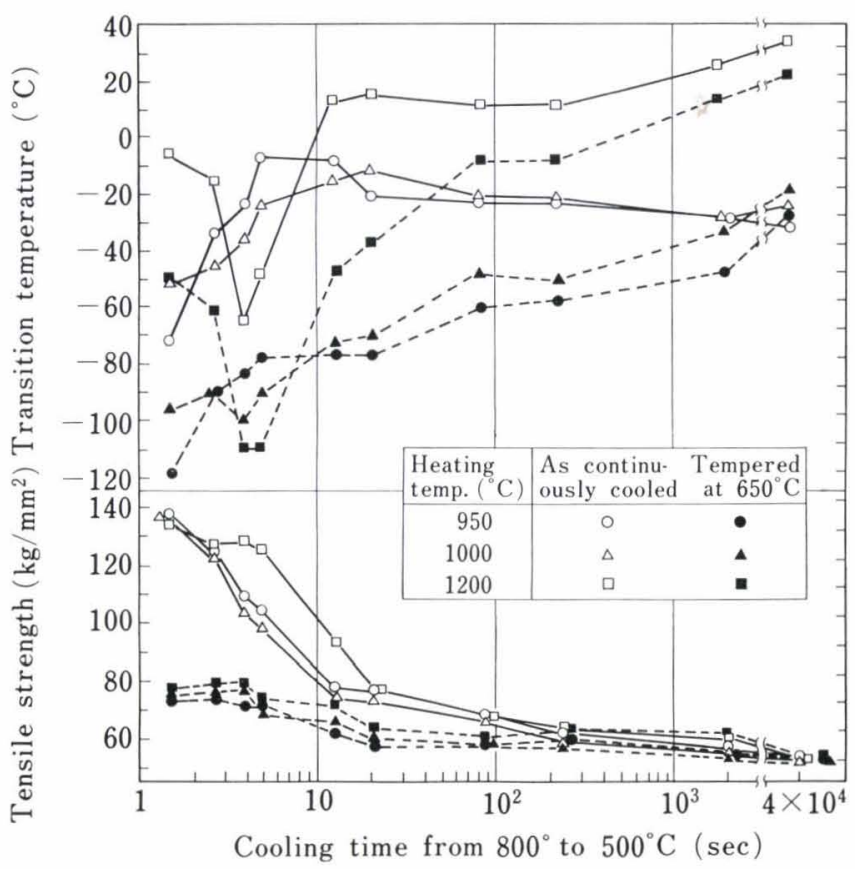

Fig. 1. Effects of cooling rate and heating temperature on mechanical properties of $\mathrm{Ni}-\mathrm{Mo}-\mathrm{V}$ steel $($ steel $\mathcal{N}$ )

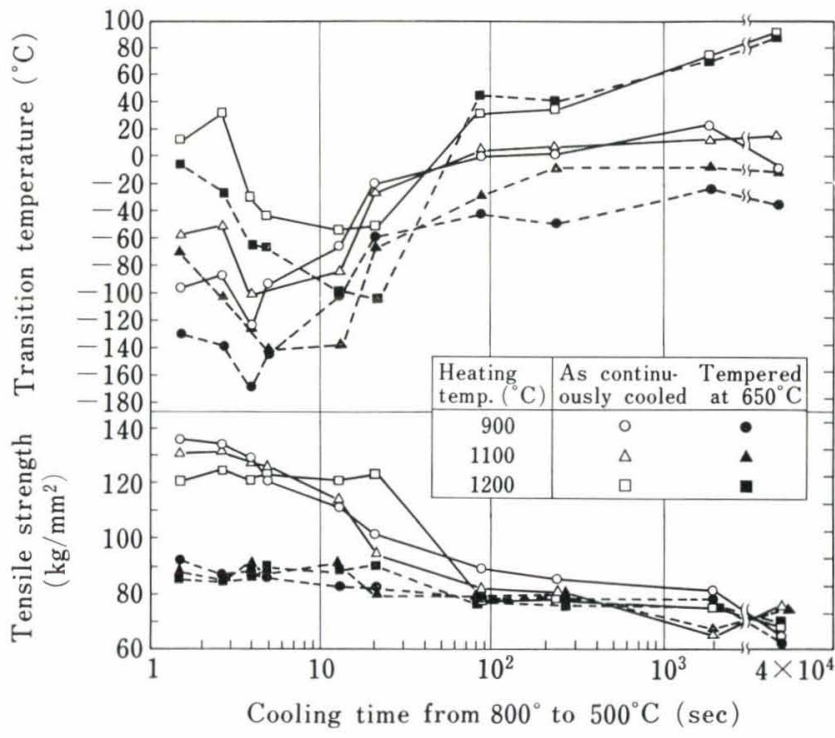

Fig. 2. Effects of cooling rate and heating temperature on mechanical properties of $\mathrm{Cu}-\mathrm{Ni}-\mathrm{Cr}-\mathrm{Mo}-\mathrm{V}$ steel (steel 7) 
The strength and toughness after tempering at $650^{\circ} \mathrm{C}$ for $1 \mathrm{hr}$ are shown also in Figs. 1, 2, and 3. In tempering, the strength decreased, but the $v T_{s}$ was improved markedly, especially in faster cooling. The

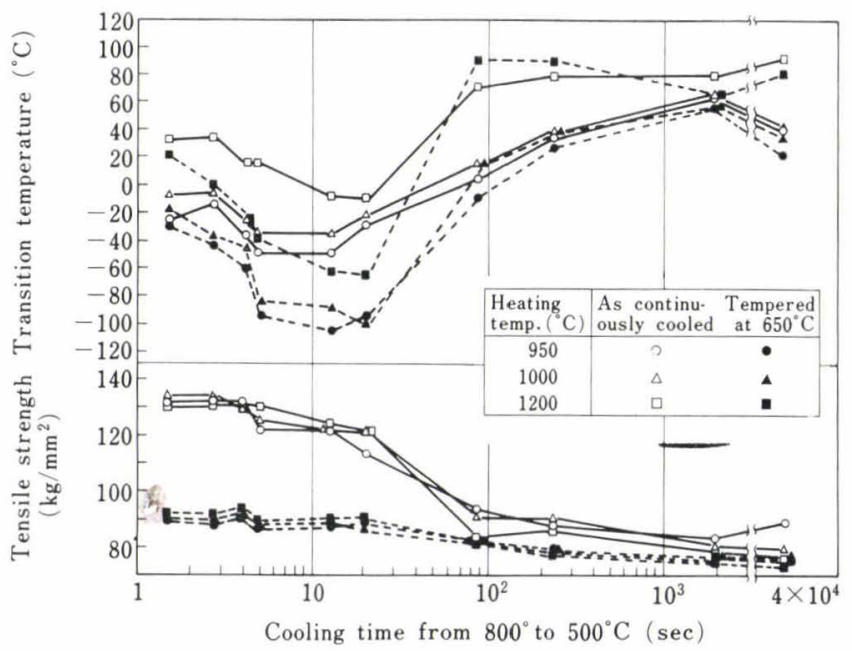

Fig. 3. Effects of cooling rate and heating temperature on mechanical properties of $\mathrm{Cu}-\mathrm{Ni}-\mathrm{Cr}-\mathrm{Mo}-\mathrm{V}-\mathrm{B}$ steel (steel 8)
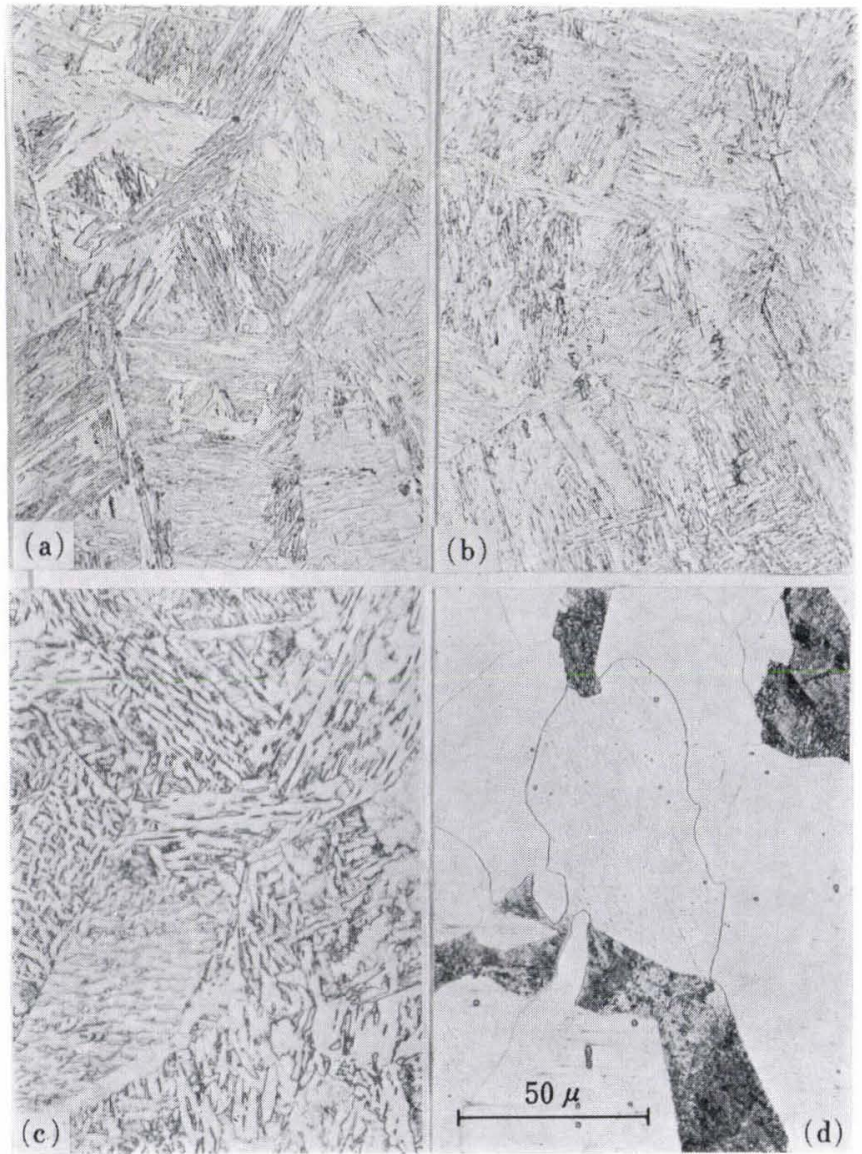

Photo. 1. Optical microstructures of $\mathrm{Ni}-\mathrm{Mo}-\mathrm{V}$ steel (steel $\mathcal{N})$ cooled from $1200^{\circ} \mathrm{C}$ with

(a) $200 \mathrm{C} / \mathrm{sec} \quad$ (T.S. $=132.9 \mathrm{~kg} / \mathrm{mm}^{2}, \quad v T_{s}=-6 \mathrm{C}$ )

(b) $75^{\circ} \mathrm{C} / \mathrm{sec} \quad$ (T.S. $=129.9 \mathrm{~kg} / \mathrm{mm}^{2}$, vTs $\left.=-66^{\circ} \mathrm{C}\right)$

(c) $14^{\circ} \mathrm{C} / \mathrm{sec} \quad\left(\right.$ T.S. $=76.5 \mathrm{~kg} / \mathrm{mm}^{2}, v T_{s}=16^{\circ} \mathrm{C}$ )

(d) $0.0075^{\circ} \mathrm{C} / \mathrm{sec} \quad$ (T.S. $=50.7 \mathrm{~kg} / \mathrm{mm}^{2}, \quad v T_{s}=32^{\circ} \mathrm{C}$ )

(a)-(d) $(\times 500)(\times 3 / 4)$ tendencies in the change of $v T s$ with cooling rate after tempering were similar to those as-cooled on continuous cooling. Then it was suggested that the impact properties were largely dependent on the initial microstructure before tempering.

\section{Microstructural Observations}

Photographs 1, 2, and 3 show the typical microstructural appearance of as continuously cooled specimens at various cooling rates in the steels $\mathcal{N}, 7$, and 8 , respectively.

In the cooling range experimented, martensite, martensite-bainite, and bainite of carbide free bainitic ferrite, ${ }^{19)}$ were produced with reducing the cooling rate. Further reducing the cooling rate, ferrite-pearlite in steel $\mathcal{N}$ and ferrite-bainite in steel 7 were obtained, but the critical cooling rate for beginning of ferrite formation in steel 8 was very small.

It should be emphasized that the superior toughness was obtained in the duplex martensite-bainite structure. The bainite in such a duplex structure could be scarcely distinguished from the martensite under an optical microscope. Careful observation, however, indicated that the region with the similar orientation
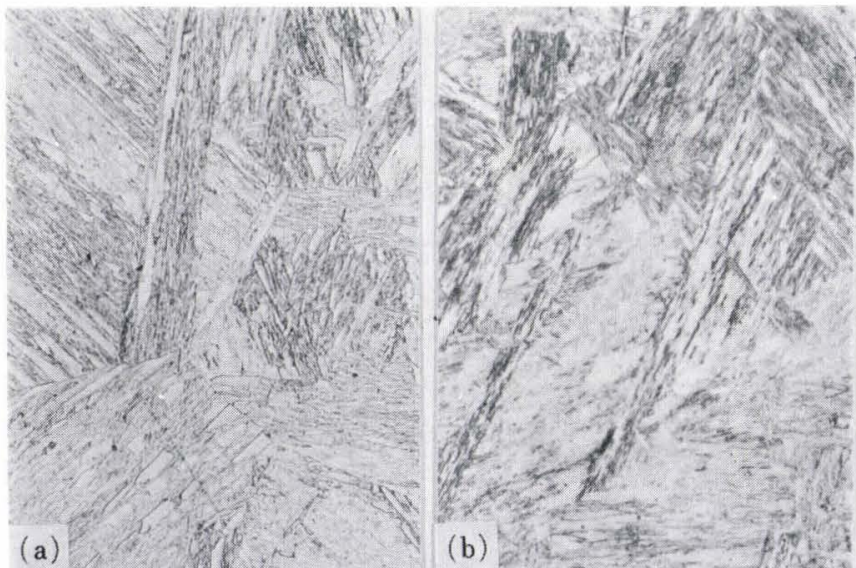

(a)
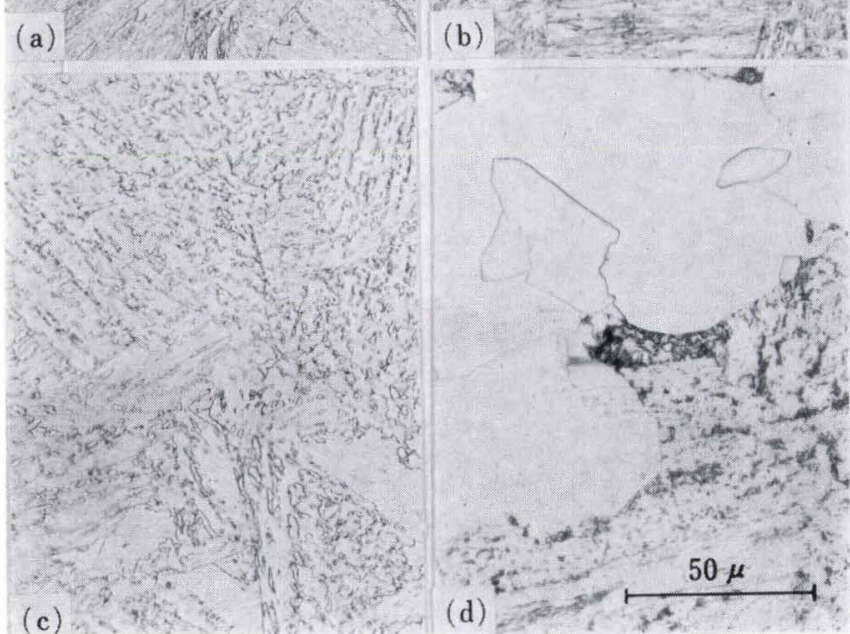

$\operatorname{sig}$
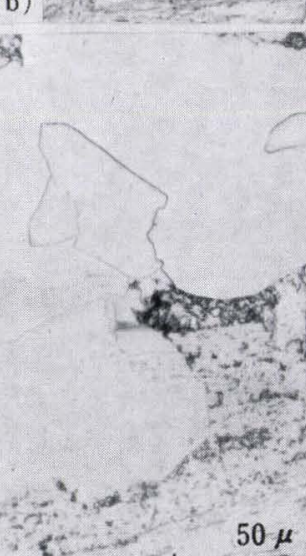

(d)

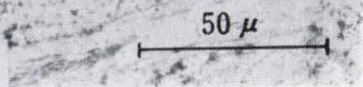

Photo. 2. Optical microstructures of $\mathrm{Cu}-\mathrm{Ni}-\mathrm{Cr}-\mathrm{Mo}-\mathrm{V}$ steel (steel 7) cooled from $1200^{\circ} \mathrm{C}$ with

(a) $200^{\circ} \mathrm{C} / \mathrm{sec}\left(\right.$ T.S. $=121.0 \mathrm{~kg} / \mathrm{mm}^{2}, v \mathrm{Ts}_{\mathrm{s}}-12 \mathrm{C}$ )

(b) $23 \mathrm{C} / \mathrm{sec} \quad\left(\right.$ T.S. $=120.3 \mathrm{~kg} / \mathrm{mm}^{2}, \quad$ Ts $=-54^{\circ} \mathrm{C}$ )

(c) $3.4^{\circ} \mathrm{C} / \mathrm{sec}\left(\right.$ T.S. $=76.7 \mathrm{~kg} / \mathrm{mm}^{2}, v \mathrm{Ts}_{\mathrm{s}}=32^{\circ} \mathrm{C}$ )

(d) $0.0075^{\circ} \mathrm{C} / \mathrm{sec} \quad$ (T.S. $=67.5 \mathrm{~kg} / \mathrm{mm}^{2}, \quad v T_{s}=92^{\circ} \mathrm{C}$ )

(a) $-(d)(\times 500)(\times 3 / 4)$ 
of martensite laths in the former austenite grain was large for the fully martensitic structure, but the austenite was finely divided in the duplex structure. The toughness became much inferior in the bainite with bainitic ferrite transformed on further reducing the cooling rate.

Photograph 4 shows a typical low carbon lath martensite. Photograph 5 shows the bainite appearing in the du-
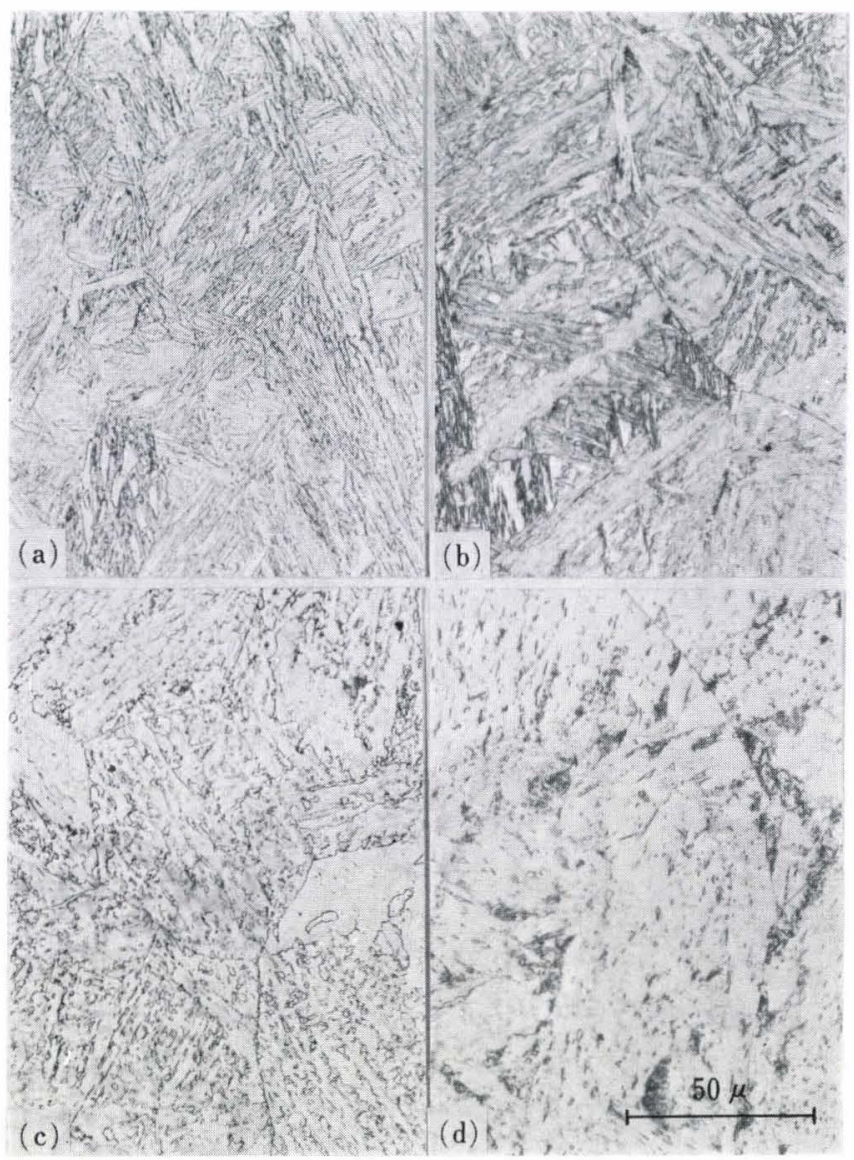

Photo. 3. Optical microstructures of $\mathrm{Cu}-\mathrm{Ni}-\mathrm{Cr}-\mathrm{Mo}-\mathrm{V}-\mathrm{B}$ steel (steel 8) cooled from $1200^{\circ} \mathrm{C}$ with

(a) $200^{\circ} \mathrm{C} / \mathrm{sec} \quad\left(\right.$ T.S. $=132.2 \mathrm{~kg} / \mathrm{mm}^{2}, \quad v$ Ts $=34 \mathrm{C}$ )

(b) $23^{\circ} \mathrm{C} / \mathrm{sec}\left(\right.$ T.S. $\left.=124.6 \mathrm{~kg} / \mathrm{mm}^{2}, v T_{s}=-6{ }^{\circ} \mathrm{C}\right)$

(c) $3.4^{\circ} \mathrm{C} / \mathrm{sec}$ (T.S. $=83.8 \mathrm{~kg} / \mathrm{mm}^{2}, v T_{s}=72 \mathrm{C}$ )

(d) $0.0075 \mathrm{C} / \mathrm{sec} \quad\left(\right.$ T.S. $\left.=75.1 \mathrm{~kg} / \mathrm{mm}^{2}, \quad v T_{s}=92 \mathrm{C}\right)$

(a)-(d) $(\times 500)(\times 3 / 4)$

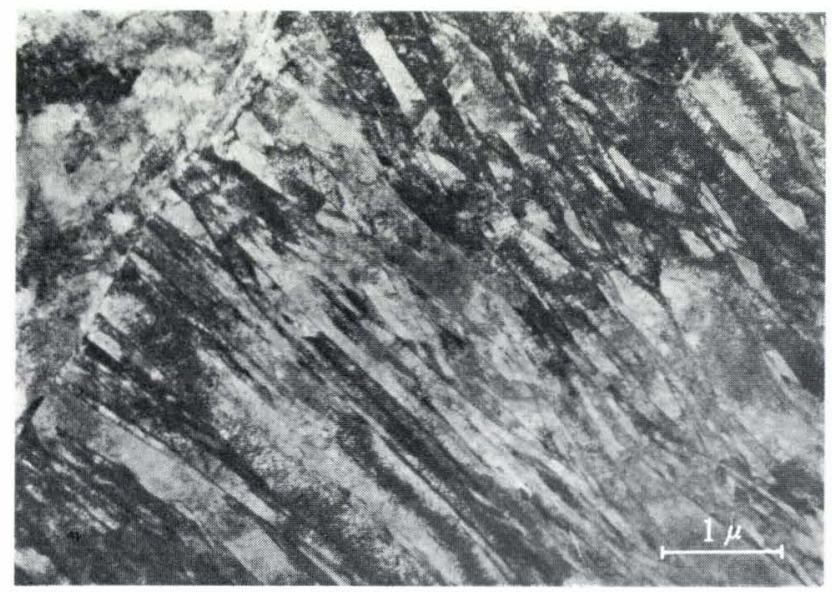

Photo. 4. Martensite formed in $\mathrm{Ni}-\mathrm{Mo}-\mathrm{V}$ steel (steel $\mathcal{N}$ ) cooled from $1200^{\circ} \mathrm{C}$ with $200^{\circ} \mathrm{C} / \mathrm{sec}$ plex martensite-bainite structures which had the superior impact properties. Here (a) and (b) are the bright field image and the dark field image using a cementite reflection, respectively. The morphology of cementite precipitation is very similar to that in the case of lower bainite in higher carbon steels. Photograph 6 shows the bainitic ferrite without carbide precipitation.
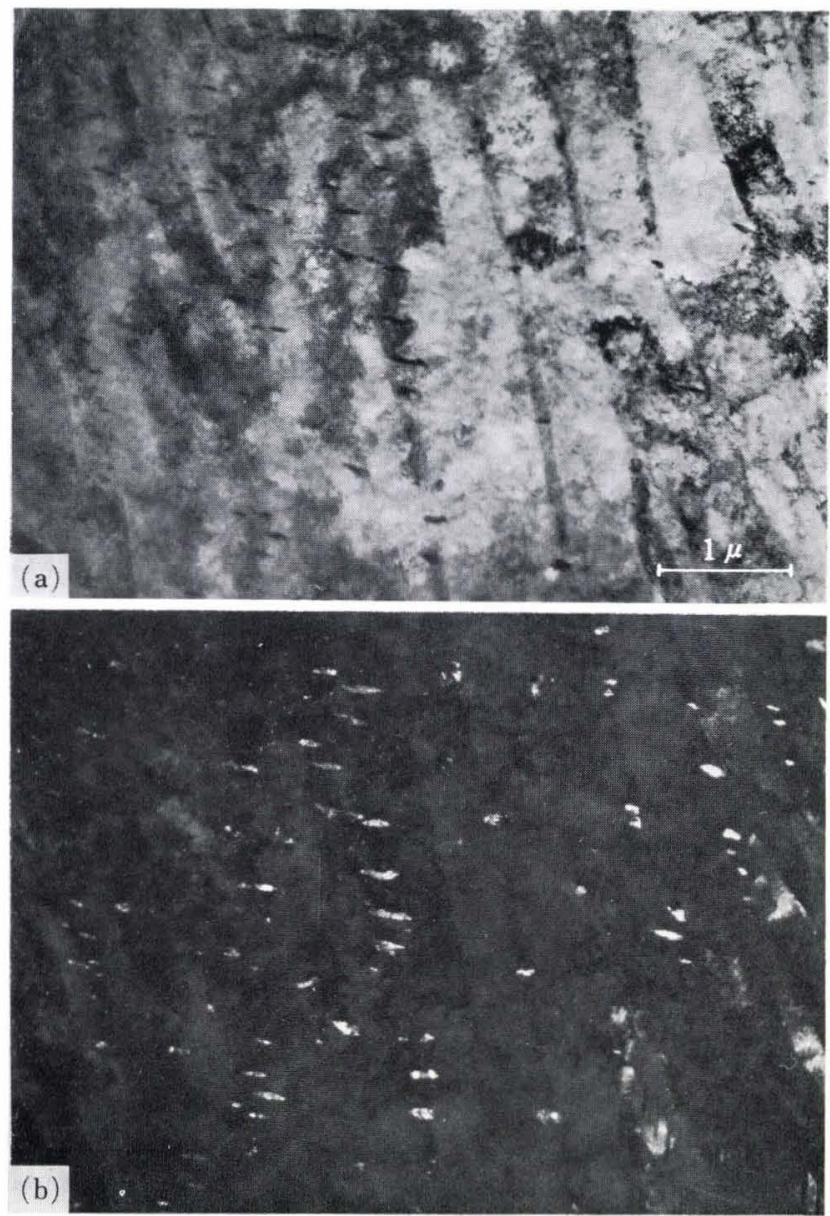

Photo. 5. Bainite formed in Ni-Mo-V steel (steel $\mathcal{N}$ ) during continuous cooling from $1200^{\circ} \mathrm{C}$ with $75^{\circ} \mathrm{C} / \mathrm{sec}$

(a) Bright field image

(b) Dark field image using a cementite reflection

(a) and (b) $(\times 20000)(\times 2 / 3)$

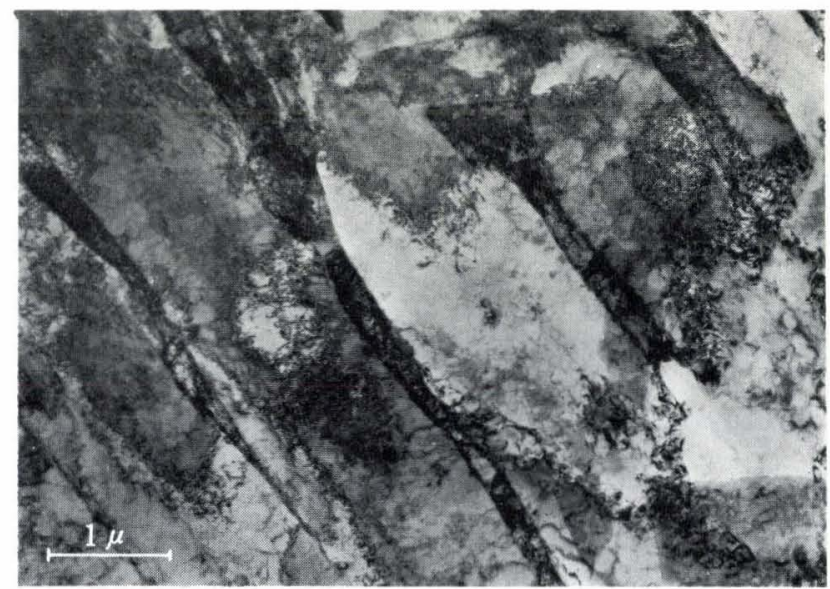

Photo. 6. Bainitic ferrite formed in $\mathrm{Ni}-\mathrm{Mo}-\mathrm{V}$ steel $(\operatorname{steel} \mathcal{N}$ ) cooled from $1200^{\circ} \mathrm{C}$ with $14^{\circ} \mathrm{C} / \mathrm{sec}$ 
The trace analysis for such martensite, bainite, and bainitic ferrite indicated the $\langle 111\rangle_{\alpha}$ growth direction and $\{110\}_{\alpha}$ habit plane. ${ }^{19)}$ Consequently, the bainites described above could be considered as the upper bainite concerning the morphology of ferrite. ${ }^{20)}$ In the previous paper, ${ }^{19)}$ the bainites in low-carbon low-alloy steels were classified to three types; Bainite $I$ type (a carbide free bainitic ferrite), Bainite $I I$ type (cementite precipitates mainly along the ferrite lath inferface) and Bainite $I I I$ type (cementite precipitates within a ferrite grain and the morphology of cementite was similar to that in lower bainite). Photographs 5 and 6 show the Bainite $I I I$ and Bainite $I$, respectively.

\section{Transformation}

Figures 4, 5, and 6 show the C.C.T. diagrams after austenitizing at $950^{\circ} \mathrm{C}$ for steels $\mathcal{N}, 7$, and 8 , respectively. As the austenitizing temperature was

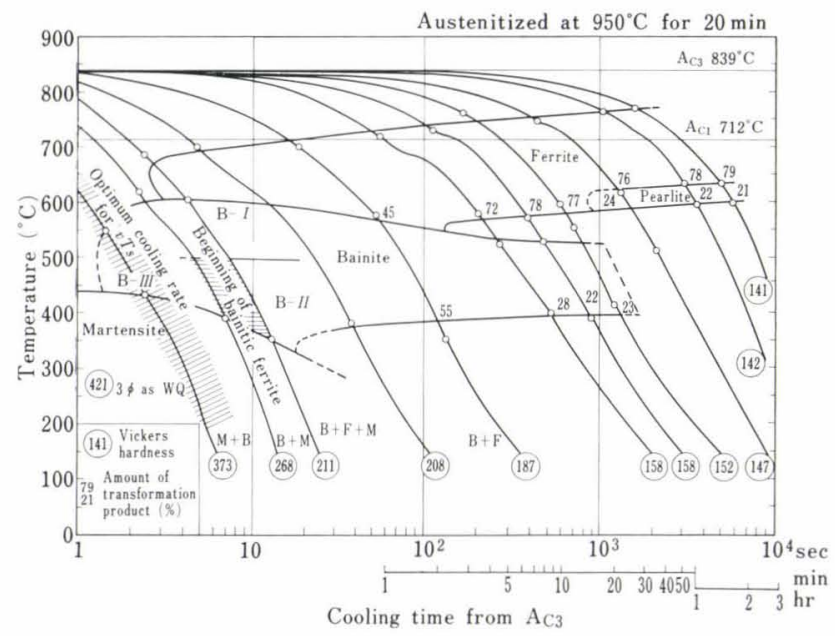

\begin{tabular}{|l|lllllllllllll}
\hline Steel & $\mathrm{C}$ & $\mathrm{Si}$ & $\mathrm{Mn}$ & $\mathrm{P}$ & $\mathrm{S}$ & $\mathrm{Cu}$ & $\mathrm{Ni}$ & $\mathrm{Cr}$ & $\mathrm{M} 0$ & $\mathrm{~V}$ & sol $\mathrm{Al}$
\end{tabular} \begin{tabular}{l|llllllllllll}
$\mathrm{N}$ & 0.15 & 0.34 & 1.25 & 0.027 & 0.017 & 0.03 & 0.19 & 0.02 & 0.13 & 0.03 & 0.032 \\
\hline
\end{tabular}

Fig. 4. C.C.T. diagram for $\mathrm{Ni}-\mathrm{Mo}-\mathrm{V}$ steel (steel $\mathcal{N}$ )

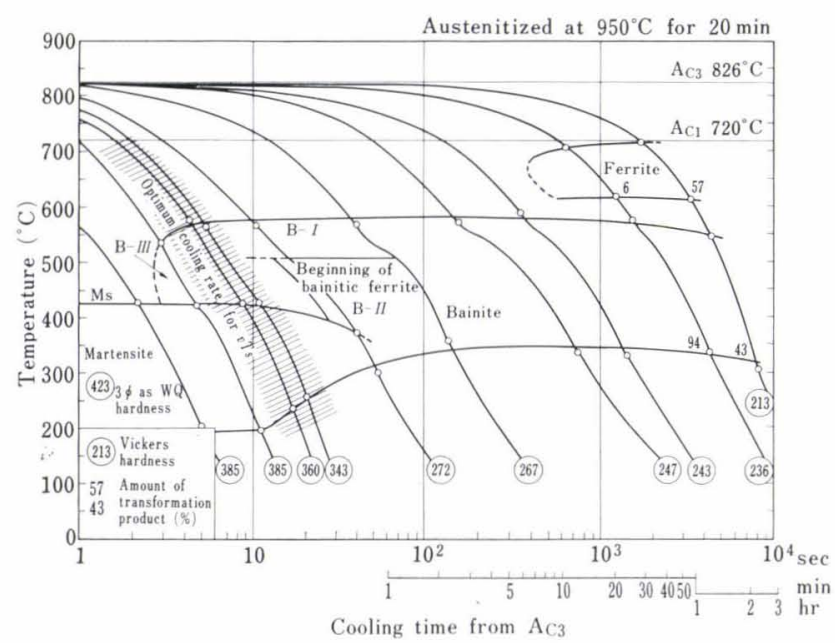

\begin{tabular}{|l|cccccccccccc|}
\hline Steel & $\mathrm{C}$ & $\mathrm{Si}$ & $\mathrm{Mn}$ & $\mathrm{P}$ & $\mathrm{S}$ & $\mathrm{Cu}$ & $\mathrm{Ni}$ & $\mathrm{Cr}$ & $\mathrm{M} 0$ & $\mathrm{~V}$ & sol Al
\end{tabular} $\begin{array}{lllllllllllll}7 & 0.12 & 0.30 & 0.83 & 0.004 & 0.005 & 0.30 & 1.11 & 0.53 & 0.49 & 0.03 & 0.031\end{array}$

Fig. 5. C.C.T. diagram for $\mathrm{Cu}-\mathrm{Ni}-\mathrm{Cr}-\mathrm{Mo}-\mathrm{V}$ steel (steel 7) raised, the critical cooling rate for the beginning of bainite formation $\left(C_{\mathrm{B}}\right)$ generally shifted to the slower cooling rate.

Figure 7 indicates that $C_{\mathrm{O}}$ is slower than $C_{\mathrm{B}}$ but faster than the critical cooling rate for the beginning of bainitic ferrite formation $\left(C_{\mathrm{BF}}\right)$. The structures obtained at the optimum cooling rate for $v T$ s included martensite and bainite. The bainite obtained at the cooling rate $C_{\mathrm{O}}$ was Bainite $I I I$ type as shown in Photo. $5 . \quad C_{\mathrm{BF}}$ nearly corresponded to the cooling rates at which hardness of $300 \mathrm{H}_{V}$ could be obtained, and the $v T_{s}$ already began to rise at this cooling rates. To obtain the duplex martensite-bainite structure (predominant

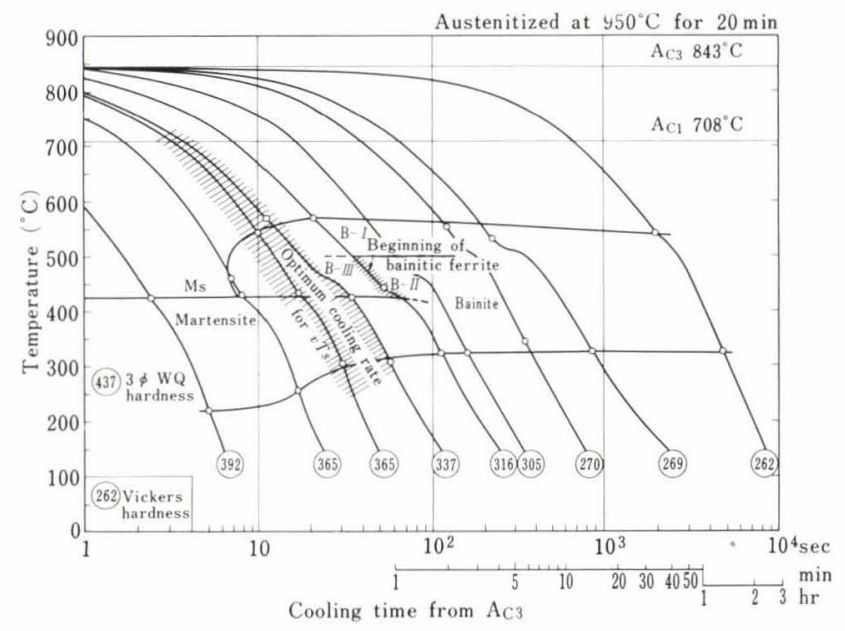

\begin{tabular}{l|ccccccccccccc} 
Steel & $\mathrm{C}$ & $\mathrm{Si}$ & $\mathrm{Mn}$ & $\mathrm{P}$ & $\mathrm{S}$ & $\mathrm{Cu}$ & $\mathrm{Ni}$ & $\mathrm{Cr}$ & $\mathrm{Mo}$ & $\mathrm{V}$ & $\mathrm{B}$ & $\mathrm{Ti}$ & sol Al
\end{tabular} \begin{tabular}{l|lllllllllllllll}
8 & 0.14 & 0.26 & 0.89 & 0.004 & 0.005 & 0.27 & 1.04 & 0.54 & 0.50 & 0.03 & 0.004 & 0.03 & 0.044
\end{tabular}

Fig. 6. C.C.T. diagram for $\mathrm{Cu}-\mathrm{Ni}-\mathrm{Cr}-\mathrm{Mo}-\mathrm{V}-\mathrm{B}$ steel (steel 8)

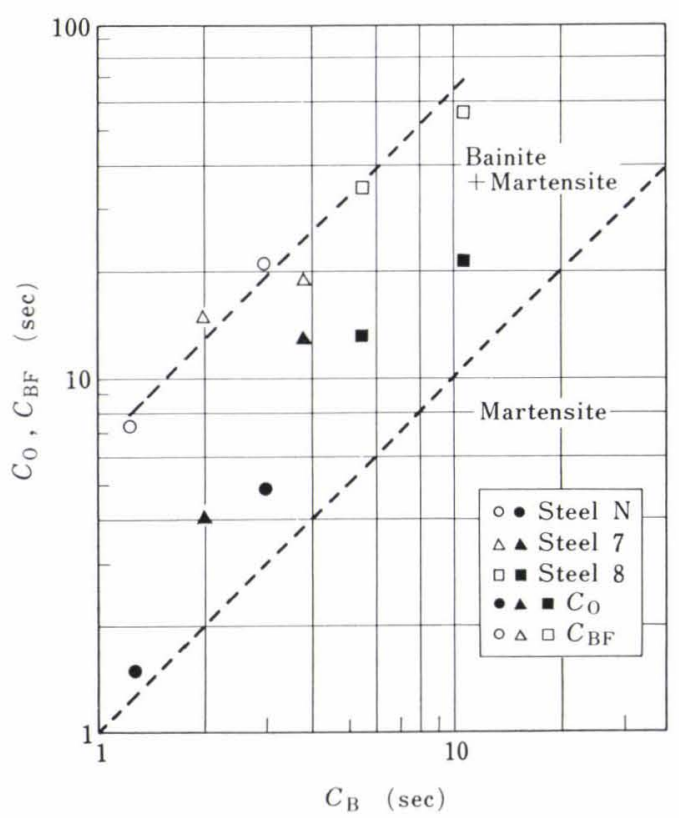

Fig. 7. Relation of optimum cooling rate for impact transition temperature $\left(C_{\mathrm{O}}\right)$, critical cooling rate for beginning of bainitic ferrite $\left(C_{\mathrm{BF}}\right)$, and critical cooling rate for beginning of bainite $\left(C_{\mathrm{B}}\right) . \quad\left(C_{\mathrm{O}}, C_{\mathrm{BF}}\right.$, and $C_{\mathrm{B}}$ are expressed in cooling time from $800^{\circ}$ to $500^{\circ} \mathrm{C}$.) 
amount of martensite) which had the superior impact properties, the bainite was Bainite III type on the continuous cooling (Figs. 4, 5, and 6). In the C.C.T. diagrams (Figs. 4, 5, and 6), the regions of Bainite $I$, $I I$, and $I I I$ and the approximate range of optimum cooling rate are shown.

\section{Effect of Austenite Grain Size}

It has been well known that the finer the austenite grain size $\left(d_{\gamma}\right)$, the more superior the impact properties are. ${ }^{1-8)}$ Figures 8 and 9 show the relations between $\log d_{\gamma}^{-1 / 2}$ and $v T s$. In these figures, the cooling rate had been employed as a parameter, but even though the

ASTM grain size number ASTM grain size number
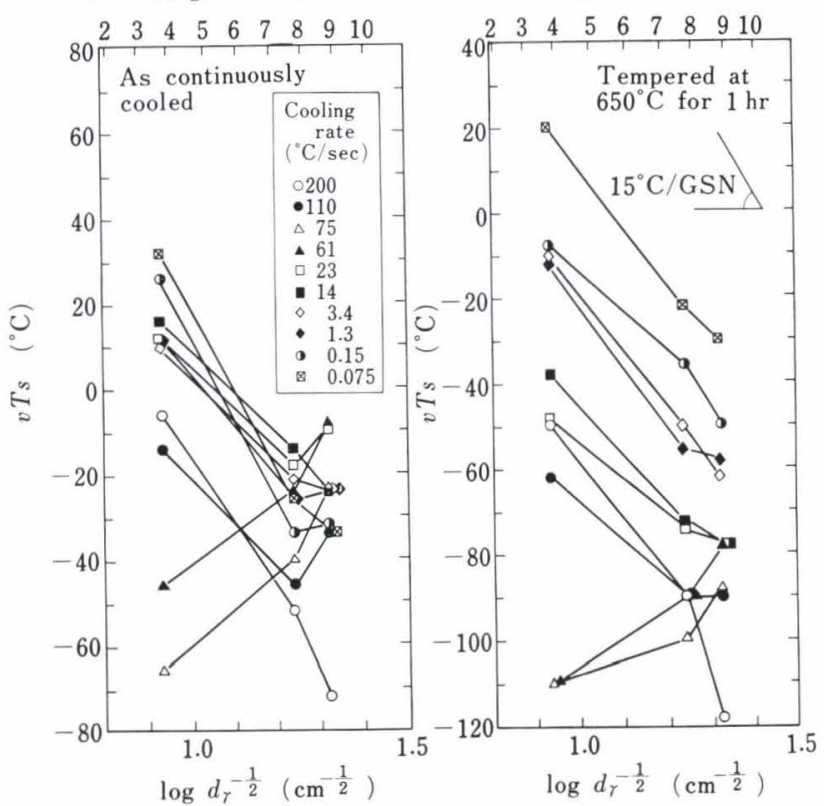

Fig. 8. Relation between austenite grain size and transition temperature for $\mathrm{Ni}-\mathrm{Mo}-\mathrm{V}$ steel $($ steel $\mathcal{N}$ )

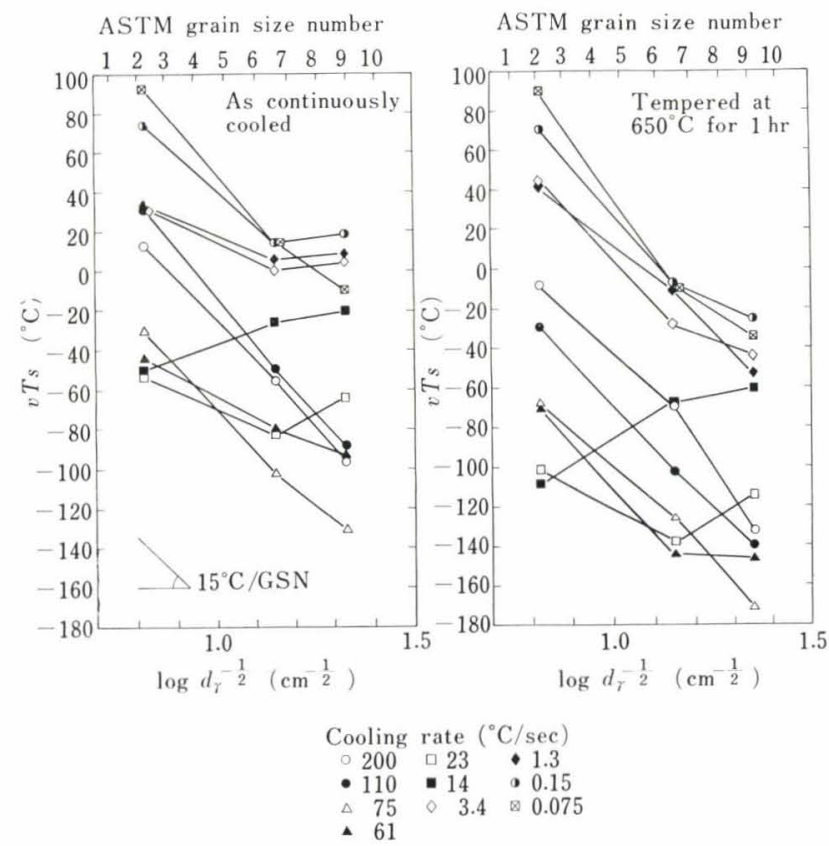

Fig. 9. Relation between austenite grain size and transition temperature for $\mathrm{Cu}-\mathrm{Ni}-\mathrm{Cr}-\mathrm{Mo}-\mathrm{V}$ steel (steel 7) cooling rates were same, the microstructures with the different austenite grain sizes were not always the same. The microstructures which had the linear correlation to the austenite grain size were the martensite, the bainite formed at high temperature, and the ferritepearlite. The dependency of $v T S$ on the austenite grain size for these structures was about $15^{\circ} \mathrm{C}$ for every ASTM grain size number, as has been reported previously. ${ }^{4)}$ Recently the detailed investigation on the relation of microstructure and fracture characteristics of low carbon tempered martensite was carried out by the independent observations of the microstructure and the fractured surface, and the effective grain size was proposed. ${ }^{21)}$ From the direct observation of fracture surface and microstructure in ferrite-pearlite, it was noted that the fracture unit was composed of several ferrite grains. ${ }^{22}$ The minimum fracture unit of pearlite in high carbon steel was observed to be a pearlite colony. ${ }^{23,24)}$ It can be considered that since there may be good correlation between the fracture unit and austenite grain size, $v$ Ts is closely dependent on austenite grain size.

In the duplex martensite-bainite structure the dependency of $v T s$ on the austenite grain size was small. In steel $\mathcal{N}$ with a small hardenability, at the same cooling rate, the microstructures were varied markedly by the austenitizing temperature. In steel 7, the dependency of $v T s$ on the austenite grain size in duplex structure was also smaller than that of martensite. This suggests that there is a case (cooling rate) where an increased austenite grain size results in improving $v T s$.

\section{Scanning Electron Microscopy of Fracture Surface}

Photographs 7, 8, and 9 show the direct correspondence between the Charpy impact fracture surfaces and microstructures of as continuously cooled specimens after austenitized at $1200^{\circ} \mathrm{C}$ in steel $\mathcal{N}$ (corresponding to Photos. 4, 5, and 6, respectively). The microscopies were performed with (a) fracture surface, (b) $45^{\circ}$ inclination to fracture surface, (c) $90^{\circ}$ inclination to fracture surface (cross section to the fracture surface). All were typical of quasi-cleavage surface with finely rugged patterns like river-mark and discontinuous aspects. Photograph 7 shows the fractography of martensite. The shapes of facet pits in the fracture unit appeared same, indicating that the unit was consisted of laths with almost the same crystallographic orientation. Photographs 8 and 9 show the fractographies of duplex martensite-B $I I I$ bainite and B $I$ type bainite respectively. The fracture unit in Photo. 8 was smaller than that in Photo. 7 , which in turn was smaller than that in Photo. 9. The fracture planes $\{112\}$ and $\{123\}$ besides $\{100\}$ were reported in a $0.3 \%$ carbon martensite, ${ }^{25)}$ but the cleavage plane determined in this study by the orientation measurements of facet pits and corresponding fracture surface with a gonio-microscope represented $\{100\}$. The results are illustrated in Fig. 10, which are the same with those obtained in the single crystal of pure iron. ${ }^{26)}$

On the basis of the direct observation of fracture 

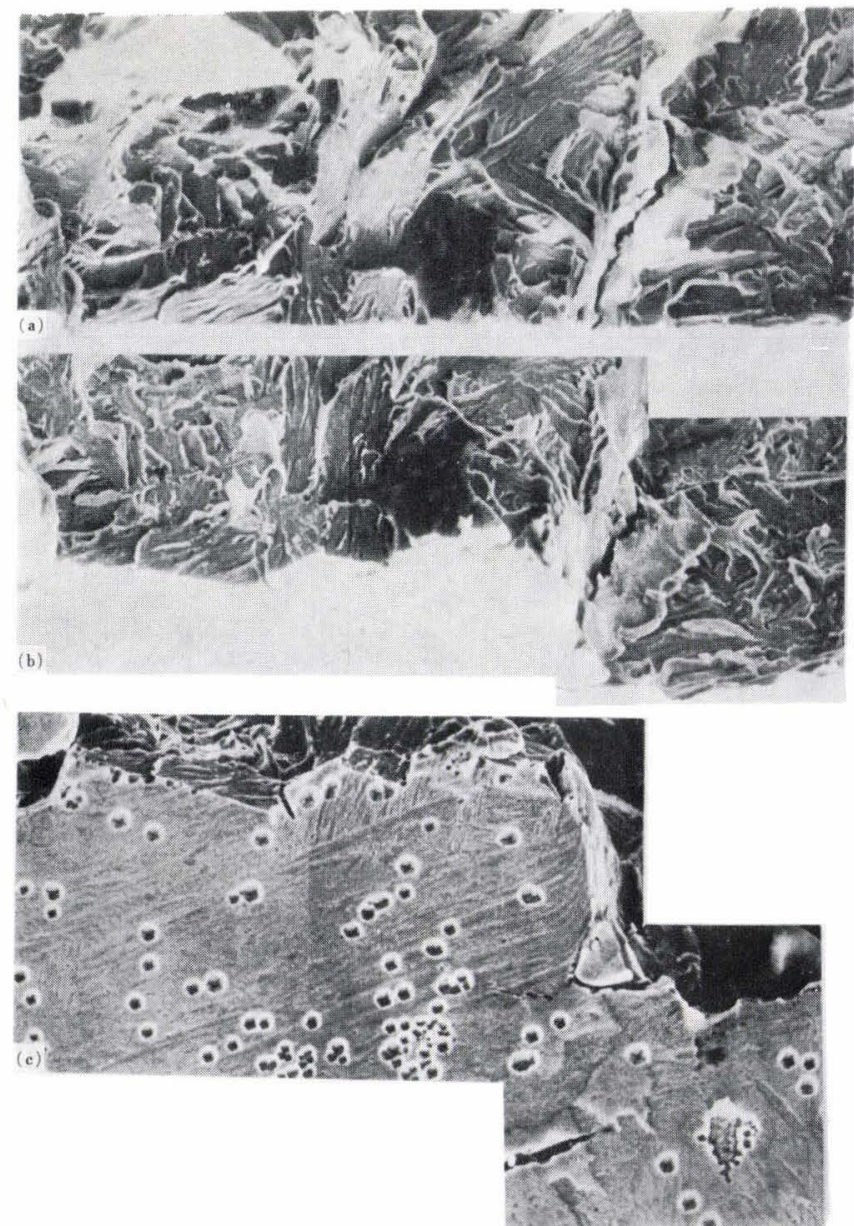

Photo. 7. Fractographs of martensite in $\mathrm{Ni}-\mathrm{Mo}-\mathrm{V}$ steel $($ steel $\mathcal{N})$ broken at $-60^{\circ} \mathrm{C}(\times 800)(\times 4 / 5)$
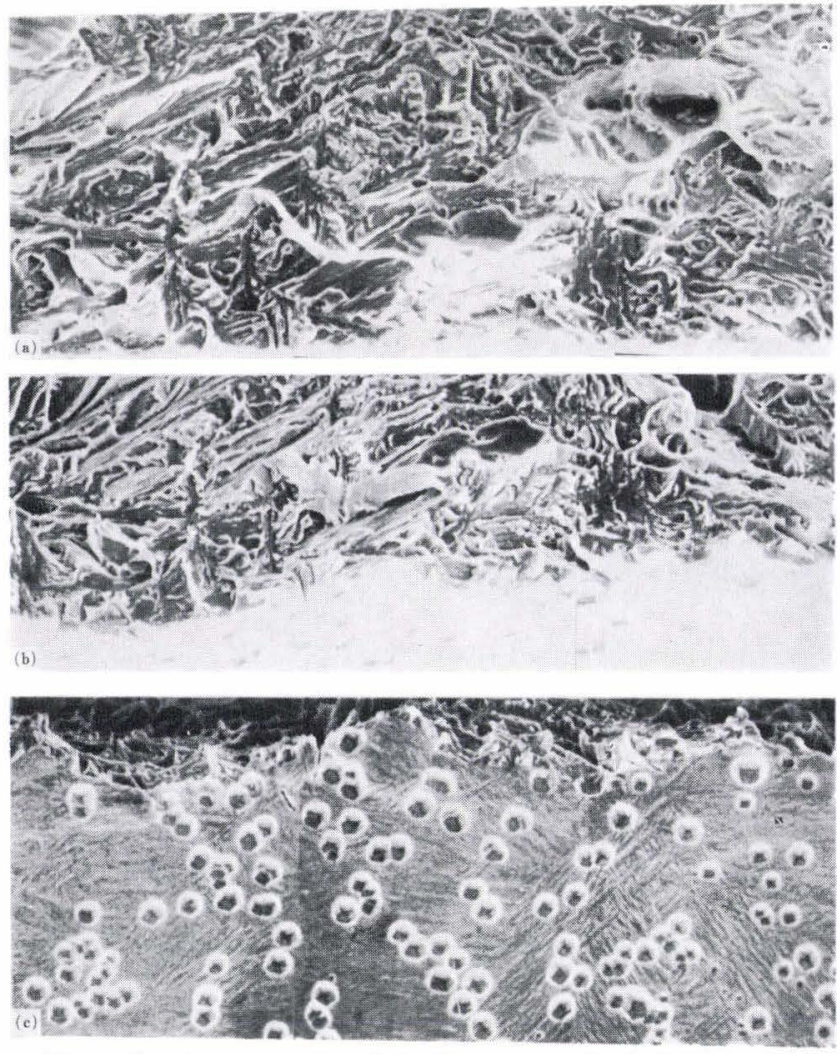

Photo. 8. Fractographs of duplex martensite-bainite structure in $\mathrm{Ni}-\mathrm{Mo}-\mathrm{V}$ steel (steel $\mathcal{N}$ ) broken at $100 \mathrm{C}(\times 800)(\times 4 / 5)$
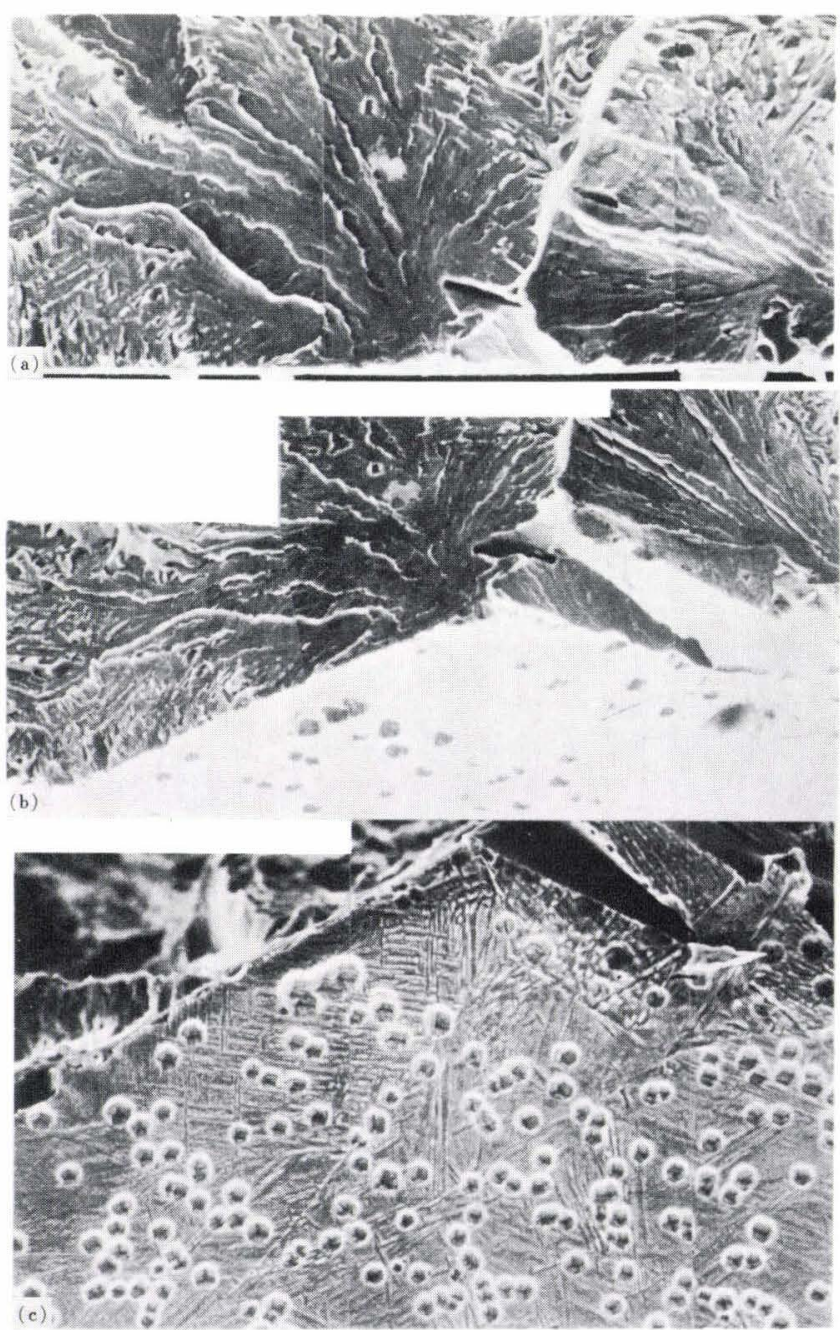

Photo. 9. Fractographs of bainite in $\mathrm{Ni}^{-} \mathrm{Mo}-\mathrm{V}$ steel (steel $\mathcal{N})$ broken at $-60^{\circ} \mathrm{C} \quad(\times 800)(\times 4 / 5)$

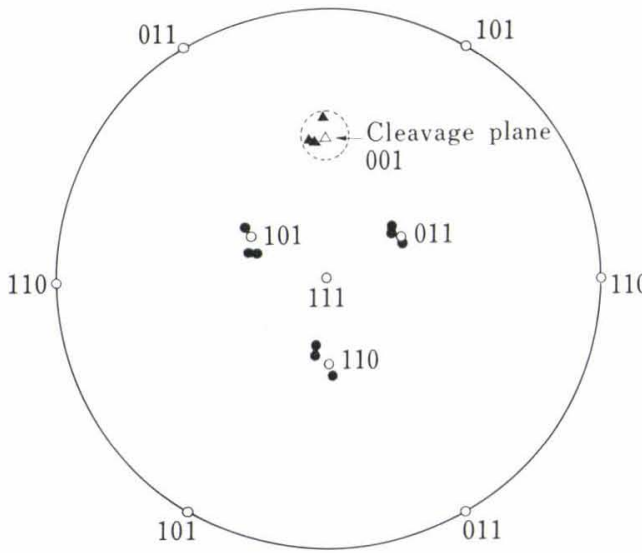

- $\triangle$ Standard projection
- Observed facet pit and cleavage plane

Fig. 10. Stereographic analysis of facet pit and cleavage plane

characteristics in detail, " the region consisting of $\{100\}$ fracture planes of which orientation differences are within a small angle' was taken as a fracture unit.22) The fracture initiated within the region at the neighbourhood of boundary of this region and propagated radially to the boundary of adjacent fracture unit. The aspects of boundary which formed the fracture unit were discussed in another paper, ${ }^{22)}$ and it was certified 
that the unit did not change with the test temperature. Under these definition, the unit crack path $(d c)$ of brittle fracture surface was measured, and correlated with $v T s$.

In Fig. 11, vTs was plotted against $\log d_{c}^{-1 / 2}$ for the continuously cooled steel 7 . There was experimentally more superior correlation in the unit crack path to the transition temperature than that of the austenite grain size to the transition temperature. It was seen that there were two groups characterized by tensile strength level. It is interesting to note that conventionally $50 \%$ martensite has been used as a criterion of hardening for the evaluation of a hardenability of steel ${ }^{27}$ and the strength with $50 \%$ martensite was about $100 \mathrm{~kg} / \mathrm{mm}^{2}$ for this steel. In the case that the strength level was less than $100 \mathrm{~kg} / \mathrm{mm}^{2}$, the microstructures were consisted of B I type bainite or ferritebainite, and the river patterns were clear and the fracture units appeared comparatively block-like, as was shown in Photo. 10. On the other hand, in the case that the strength level was more than $100 \mathrm{~kg} / \mathrm{mm}^{2}$, the microstructures were consisted of martensite or martensite-B III type bainite. The fractographs revealed that the river patterns were not linear-like and the fine microstructure might have the resistance against propagation of microfracture.

The size of fracture unit did not vary with the test temperature, but as the temperature was raised, the fine ductile zones were observed to be networks around the brittle fracture region. ${ }^{28)}$ As the temperature was raised still more, the ductile fracture region with the size of fracture unit was observed. ${ }^{28)}$

\section{Discussions}

In the relation of the impact transition temperature

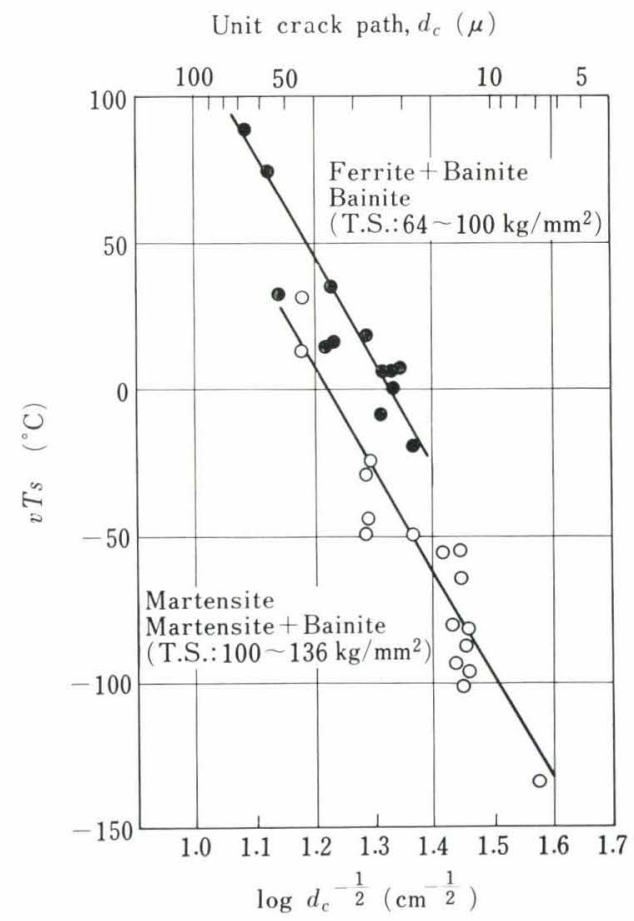

Fig. 11. Relation between unit crack path and $v$ Ts for continuously cooled $\mathrm{Cu}-\mathrm{Ni}-\mathrm{Cr}-\mathrm{Mo}-\mathrm{V}$ steel (steel 7) with the cooling rate on continuous cooling, similar characteristics were observed between the as-cooled specimen and the tempered one. Consequently, it is considered that the transition temperature essentially depended on the microstructures formed by transformation during continuous cooling from the austenitizing temperature. It was clarified that the duplex martensite-B III type bainite had superior impact properties.

It was difficult to compare the toughness of martensite with that of fully B III type bainite, because of difficulties to obtain the fully B III type bainite by continuous cooling in such low-carbon low-alloy steels. Although the carbide morphology of bainite was quite different from that of martensite, ${ }^{19)}$ the aspects of fracture surfaces scarecely revealed different appear-
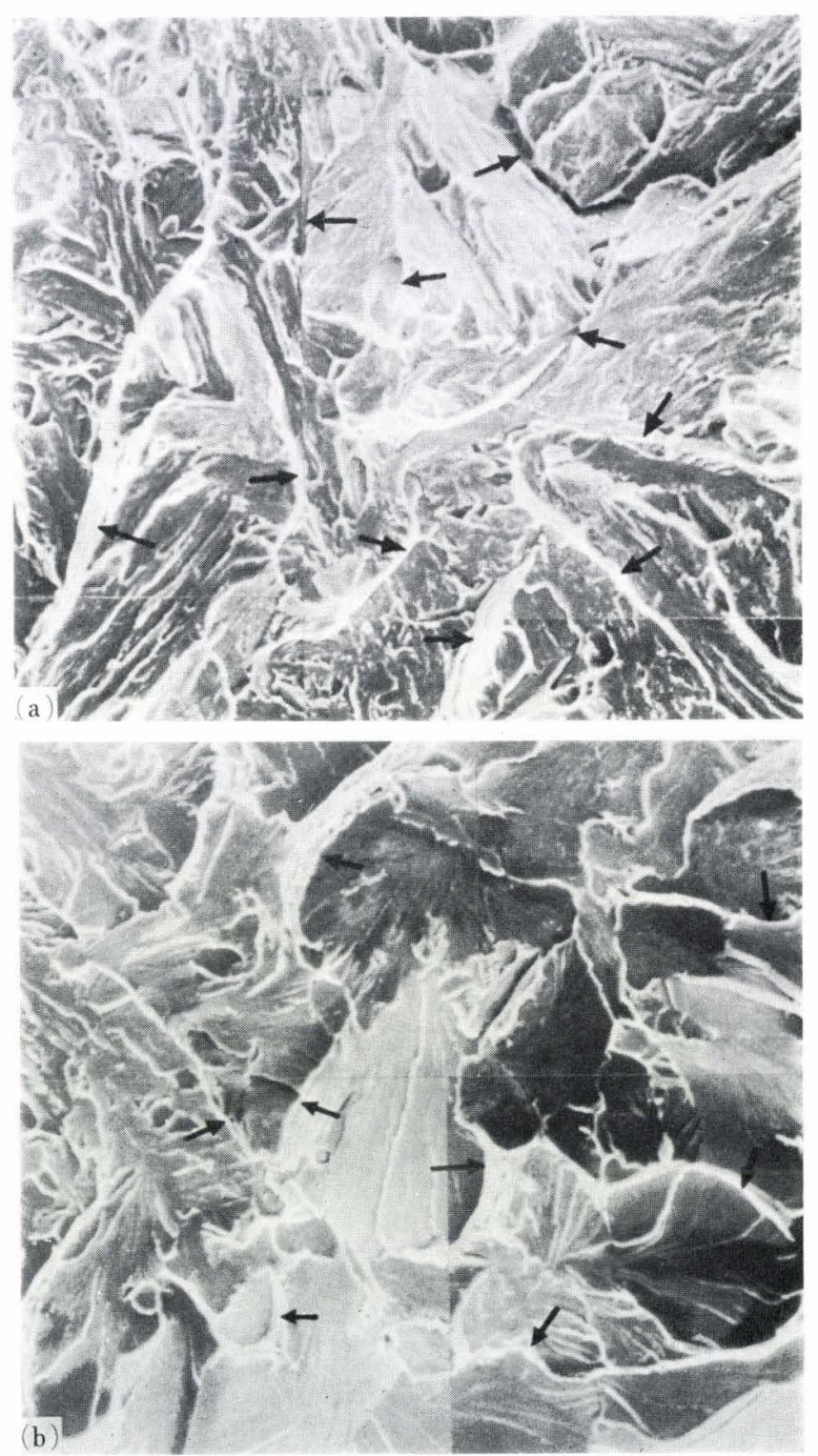

Photo. 10. Unit crack path of typical microstructures formed in $\mathrm{Cu}-\mathrm{Ni}-\mathrm{Cr}-\mathrm{Mo}-\mathrm{V}$ steel (steel 7) during continuous cooling from $1200^{\circ} \mathrm{C} \quad(\times 600)$ $(\times 3 / 4)$

(a) Duplex martensite-bainite structure broken at $-100^{\circ} \mathrm{C}$

(b) Ferrite-bainite structure broken at $-20^{\circ} \mathrm{C}$ 
ances. The habit plane and growth direction of both martensite and bainite were $\{110\}_{\alpha}\langle 111\rangle_{\alpha}$ and the thickness of lath in bainite was not less than that in martensite, ${ }^{19)}$ so there could be no substantial differences contributed to the toughness. The dislocation densities should have some effects on the toughness essentially, but it should be pointed out that the dependencies of transition temperature on the cooling rate were similar before and after tempering.

It has been shown previously that the bainite had superior strength and toughness. ${ }^{13,29,30}$ In evaluation of toughness of different microstructures, it has to be made in the same strength level, but to make the strength level of martensite as same as that of untempered bainite, martensite has to be tempered at the low temperature which is not preferable to the toughness. So, generally it is difficult to evaluate the superiority of toughness among different microstructures. In the present experiment, however, the strength was almost the same in the range near the optimum cooling rate for $v T_{s}$, and there was little strength difference among various structures after tempering, so it was able to evaluate the toughness at the same strength level.

Photograph 11 shows the direct correspondence between fracture surface and the duplex structures etched by $2 \%$ nital, exhibiting somewhat different etching sensitivity. The direction of crack propagation (shown by arrows) changed at the boundary of the region etched darkly ( $B$ in Photo. 11). This structure appeared apparently prior to martensite transformation ( $\mathrm{M}$ in Photo. 11). Although it appeared to
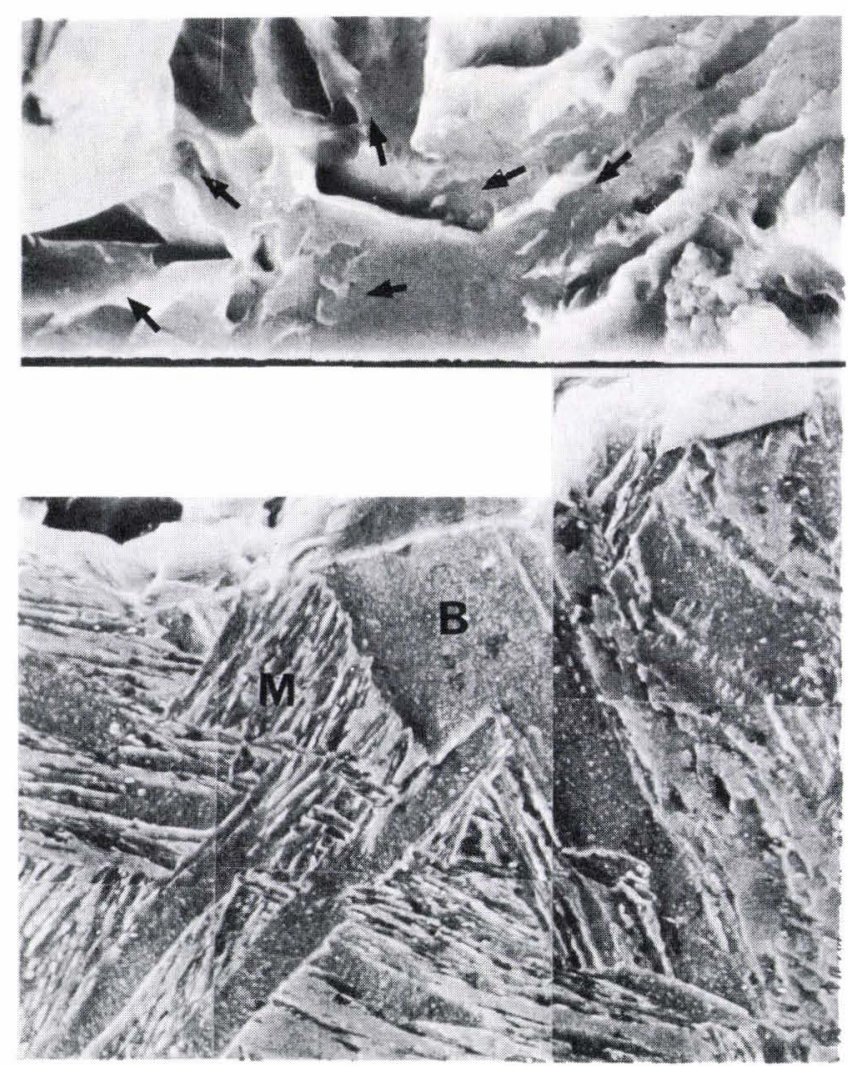

Photo, 11. Correspondence of duplex martensite-bainite structure to fractured surface $(\times 10000)$ $(\times 4 / 5)$ be uncertain that this is bainite or autotempered martensite, the carbide morphology was quite similar to that of B III type bainite. The fracture path changed its direction at the boundary of bainite but within the lath (B) there was no evidence of the resistance against fracture, and consequently, the lath itself could not seem particularly effective against brittle fracture.

Recently it was reported ${ }^{31)}$ that martensite was tougher than lower bainite but duplex martensitebainite structure was tougher than those structures. In this case, however, although the bainite was lower bainite different from upper bainite, it was suggested that the boundary between different microstructures might play important role to enhance the toughness.

The observation of fracture surface revealed that there was the correlation between $d c$ and $v T s$, and the martensite-bainite structure with superior toughness showed the finest fracture unit. The superior toughness of the duplex structure is probably related to the mode of bainite formation. In other words, the bainite partitioned the austenite grain prior to the martensite transformation as well as providing the increased transformation sites.

To obtain such a duplex structures on continuous cooling, the bainite should be B III type bainite. Because the impact properties depended on the fine substructure, the partitioning by bainitic ferrite formed at the high temperature seems not effective for the toughness. It is because that the lath of bainite itself and the fracture unit are large and the austenite with enriched carbon produces the high carbon transformation products. The partitioning by martensite seems effective, but the controlling of martensite transformation in low-carbon low-alloy steel is difficult.

\section{Summary}

The impact properties of some high tensile strength steels were investigated in relation to the cooling rate on continuous cooling and the austenite grain size. The direct observations of impact fracture surface in relation to microstructures were performed with the scanning electron microscope. The results obtained are as follows:

(1) There was the optimum cooling rate for the impact transition temperature.

(2) The transition temperature characteristics against the cooling rate after tempering were similar to that of as continuously cooled ones.

(3) The optimum cooling rate varied with the hardenability of steel and as the austenitizing temperature was raised, it shifted to the lower cooling rate.

(4) The optimum cooling rate was smaller than the critical cooling rate for the beginning of bainite formation, and the electron microscopy revealed that the microstructure obtained on the optimum cooling rate was consisted of martensite and bainite.

(5) The morphology of carbide in the bainite was similar to that in lower bainite of a higher carbon steel, but the trace analysis for such bainite revealed that it had the same lath-like morphology with a $\langle 111\rangle_{\alpha}\{110\}_{\alpha}$ habit as that in the upper bainite and the 
lath martensite. (This bainite in a low-carbon lowalloy steel was designated as Bainite $I I I$ type in the previous paper. ${ }^{19)}$

(6) The transition temperatures of microstructures consisted of ferrite-pearlite, martensite and bainite formed at higher temperature had the correlation to the austenite grain size, but in the duplex martensitebainite structure, the austenite grain size dependency of transition temperature was small. There was a case that, even though the austenite grain coarsening occurred, the transition temperature was improved.

(7) The direct observations of fracture surface in relation to the microstructure with a scanning electron microscope were performed. The orientation measurements of facet pit and fracture surface revealed that the crystallographic orientation of fracture surface was $\{100\}$.

(8) On the basis of the direct observation of fracture characteristics in detail, "the region consisting of $\{100\}$ fracture planes of which orientation differences are within a small angle" was taken as a fracture unit and in this unit a crack nucleated, propagated, and was arrested. It was experimentally clarified that there was a better correlation of the transition temperature to the unit crack path than to the austenite grain size. The fine aspect of fracture surface, however, in a fracture unit was dependent on the microstructure, such as martensite and ferrite-pearlite.

(9) The fracture unit became finest in the duplex martensite-bainite structure, and it was extremely large in the bainite mainly consisted of bainitic ferrite.

(10) These results suggested that the role of bainite in the duplex structure was the partitioning of austenite grain prior to the martensite transformation.

\section{Acknowledgements}

The authors wish to thank Dr. M. Sumitomo, General Manager, Central Research Laboratories, Sumitomo Metal Industries, Ltd., for permission to publish this article.

\section{REFERENCES}

1) R. A. Grange: Trans. ASM, 59 (1966), 26.

2) S. Kanazawa, S. Suzuki, and K. Imano: Tetsu-to-Hagané,
56 (1970), S306.

3) D. Hadwick and K. R. Pirt: JISI, 196 (1960), 301.

4) B. Cina and P. Jubb: JISI, 195 (1959), 329.

5) H. Kubota, T. Ohsuga, J. Tanaka, and C. Ohuchi: Proc. Japan Inst. Metals (April, 1970), 156.

6) W. S. Owen, D. H. Whitmore, M. Cohen, and B. L. Averbach: Weld. J., 36 (1957), 503s.

7) J. M. Hodge, R. D. Manning, and H. M. Reichhold: Trans. Met. Soc. AIME, 185 (1949), 233.

8) J. H. Gross and R. D. Stout: Weld. J., 35 (1956), 72s.

9) N. J. Petch: Phil. Mag., 3 (1958), 1128.

10) G. Burns and C. Judge: JISI, 182 (1956), 292.

11) W. Barr and A. J. K. Honeyman: JISI, 157 (1947), 243.

12) G. Birkbeck: JISI, 206 (1968), 909.

13) E. S. Davenport: Trans. Met. Soc. AIME, 209 (1957), 677.

14) J. C. Danko and R. D. Stout: Trans. ASM, 49 (1957), 189.

15) E. H. Kottcamp, Jr. and R. D. Stout: Weld. J., 38 (1959), $435 \mathrm{~s}$.

16) T. Kunitake: Tetsu-to-Hagané, 54 (1968), 710.

17) T. Kunitake and H. Ohtani: Sumitomo Metal, 19 (1967), 311.

18) T. Taoka, F. Furubayashi, and S. Takeuchi: Jap. J. Appl. Phys., 4 (1965), 120.

19) Y. Ohmori, H. Ohtani, and T. Kunitake: Tetsu-to-Hagané, 57 (1971), 1690; Trans. ISIJ, 11 (1971), 250.

20) Y. Ohmori and R. W. K. Honeycombe: Proc. Int. Conf. Sci. Tech. Iron and Steel, Tokyo, (1970).

21) S. Matsuda, T. Inoue, and M. Ogasawara: Trans. JIM, 9 (1968), 343; 11 (1970), 36.

22) F. Terasaki and H. Ohtani: Tetsu-to-Hagané, 56 (1970), S 211, (to be published in Tetsu-to-Hagané).

23) A. M. Turkalo: Trans. AIME, 218 (1960), 24.

24) F. Terasaki and H. Ohtani: Tetsu-to-Hagané, 56 (1970), S 550 .

25) U. H. Lindborg and B. L. Averbach: Acta Met., 14 (1966), 1583.

26) F. Terasaki: Acta Met., 15 (1967), 1057.

27) J. M. Hodge and M. A. Orehoski: Trans. Met. Soc. AIME, 167 (1946), 627.

28) F. Terasaki and H. Ohtani: Tetsu-to-Hagané, 57 (1971), S 239 .

29) K. Suzuki et al.: Mitsubishi Heavy Industries Technical Review, 4 (1967), 271.

30) H. Nakajima and T. Araki: Tetsu-to-Hagané, 54 (1968), S 209, S 522; 56 (1970), S 157.

31) D. P. Edwards: JISI, 207 (1969), 1494. 